\title{
The Era of Competitive Advantage Through Relationship Marketing In Ghana
}

\author{
George Kankam Jr. \\ Department of Marketing and Entrepreneurship, University of Education, Winneba - Ghana
}

\begin{abstract}
It has become imperative for business entities to strategically think about how to attract and subsequently retain customers. The study therefore seeks to examine the impact of relationship marketing strategy on gaining competitive advantage. Empirically, the study focused on Ghanaian banks. Simple random sampling technique was used to select customers of Ghanaian Banks. A total of 30 respondents were used for the study. Data was analyzed using structural equation modelling (PLS-SEM) with SmartPLS 3.0. The study revealed that, the six relationship marketing constructs jointly had positive significant effect on competitive advantage.
\end{abstract}

Keywords: Relationship marketing, Competitive advantage, Marketing strategies, Customers.

DOI: $10.7176 / \mathrm{EJBM} / 13-1-04$

Publication date: January $31^{\text {st }} 2021$

\section{Introduction}

The "house cleaning exercise" embarked upon by Central Bank of Ghana had both positive and negative consequences in the Ghanaian banking sector. Undoubtedly, the banking sector has become quite turbulent because of closure of some banks and increasing pace of panic withdrawal emanating from luck of trust between the banking institutions and their customers. There is therefore the need to institutionalize a workable strategy with the strategic intent of attracting and retaining customers and that is exactly what this study seeks to undertake. That is; to establish an empirical fact that within the Ghanaian context the banks can equally gain competitive advantage among each other through relationship marketing.

Ambler (2004) asserts that successful marketing strategy must focus not only on winning new customers but also on developing the loyalty of the hard-won existing ones. Ndubisi (2004) reported that more and more firms are capitalizing on strong firm-customer relationship to gain invaluable information on how best to serve customers and keep them from defecting to competing brands. The current trend in the Ghanaian banking sector is quite worrying where managers have to spend sleepless night strategizing on how to attract and retain potential customers. This assertion was confirmed by Das (2009) that, nowadays business entities strive to provide highquality goods and services with the rational to retain their hard-won customer for long-time profit. This scholarly work reported here investigates the impact of six underpinnings of relationship marketing - trust, commitment, communication, bonding, competence and conflict handling - on sustained competitive advantage among Ghanaian banks.

\section{Literature review}

Conceptualization of relationship marketing as a discipline can be trace to Christopher (2001); Gummesson (2009) and Lindgreen, (2004) in the field of service marketing. Kotorov (2003) suggested that business strategies should be based on the goals, plans, development and establish a relationship climate that will promote a dialogue between a firm and its customers that aims to imbue an understanding confidence and respect of each other's capabilities and concerns when enacting their role in the marketplace and in society. Lambert (2010) viewed it as strategic, process oriented, cross-functional, and value-creating for buyer and seller a means of achieving superior financial performance. Chen and Popovich (2003) stated that is a comprehensive business and marketing strategy that integrates technology, process, and all business activities around customers. Lambert (2010) viewed it as strategic, process oriented, cross-functional, and value-creating for buyer and seller a means of achieving superior financial performance. Am of the opinion that relationship marketing is about building organizational cultural ties with customers with the strategic intent in response to both organizational and consumer's needs.

\section{The "underpinnings" of relationship marketing}

Scholarly researchers in the field of marketing have empirically established key virtues that should characterize relationship marketing practices. Notably are; trust (Churchill \& Surpernan, 2002), communication and conflict handling (Morgan \& Hunt, 2004), Commitment (Ndudisi, 2007), Bonding and competence (Narteh, 2013). The study adopted these constructs and links it to sustained competitive advantage.

\section{Trust}

Trust is based on recurring, dependable recharges and adherence to expected behaviour (Buttle, 2006). Trust is proven empirically to be comprising of three elements; predictability, dependability and faith. Ndubisi (2004) 
found that trust contributes more significantly in building loyalty and commitment. Bell (2008) stated that, when an organization wants to build a long last relationship with customers trust should be ensured. Thus, the importance of trust to an organization cannot be over emphasized. It can early propel the organization to achieve its predetermined goals. Trust is said to be the bedrock of reliability and integrity (Morgan \& Hunt, 2004). Trust, which exists when one party has confidence in an exchange partner's reliability and integrity," is a central component in all relational exchanges (Morgan \& Hunt, 2004). The final concept necessary to build relationships is trust. In business, trust refers to the confidence that one partner, the customer, has in the business's reliability and integrity to deliver goods and services (Proctor, 2000). Trust relates to the belief that a customer has in an honest investment and engagement with the service provider (Pointer, 2006). In the banking context, trust is defined as customer confidence in the quality and reliability of the services offered by the organization (Johnson, 2009). It becomes the moral values that are established to enhance their business relationship between banks and customers. Dwyer (2007) argue that trust is considered the foundation of strategic partnerships, and it seems to be a mediating or intermediary element in provider-customer relationships. Prior studies find trust to be the core of the relational approach and consider it key to the development of the notion of commitment in provider-user relationships (Murphy, 2003; Phan, 2003). According to Urban, Sultan, and Qualls (2000), trust is also considered as a key element in establishing long-term relationships with customers and in maintaining a company's market share. Therefore, based on the prior empirical findings, hypothesis 1 is proposed as below:

H1: Relationship marketing has a positive relationship on customer trust.

\section{Commitment}

Commitment is defined as a state or a quality of being committed to a cause, policy or person. In otherwise commitment is a pledge or undertaking made by a business entity to a customer in the delivery of their promises. Thus, in my candid opinion, an engagement to commitment will in the long-run restrict the firms' freedom of action in behaving contrary. Literature has revealed that, this subject has different meaning from other disciplines ((Becker, 2001). Moorman, (2003) a marketing scholar defines commitment as an enduring desire to maintain a valued relationship. He believes that for an organization to succeed in turbulent business environment it should commit its industrial proceedings towards attainment of valued relationship. Commitment refers to an implicit or explicit pledge of the continuity of a relationship between exchange partners (Dwyer, 2007). As Narteh (2013) stated, commitment is the most advanced phase of partners' interdependence. A confirmatory analysis was made by Ndubisi (2004), showing that a firm that is highly committed to relationship building continues to enjoy the benefit thereof. Commitment is also seen as a focal relationship construct preceding a customer's relational behaviours (Garbarino \& Johnson, 2001). The most desirable aspect of relationship is commitment which is the foundation upon which relationships are built and has been described as an important determinant factor in relationship foundation Ndubisi (2004). McDonald (2007) reveals that when customer commitment is based on shared values and identification, it has a uniformly positive impact on customer loyalty. Several other studies confirm a significant interaction of affective commitment and continuance commitment on loyalty (Fullerton, 2003; Chan, 2005). Therefore, based on the prior empirical findings, hypothesis 1 is proposed as below:

H2: Relationship marketing has a positive relationship on customer commitment

\section{Communication}

Communication is vital when it comes to information dissemination within and outside the organizational framework. Ambiguity in communication can cause total chaos which can hinder the attainment of an organization's objectives. Adamson, Chan and Hanford (2003) reported that, communication is all of informal and formal intercourses that cause to exchange the meaningful and in time information among purchaser and seller. Sin and Tse (2005) also defined communication as an exchange and sharing of valuable and reliable information in time officially or unofficially between partners of a relationship. Ndubisi (2004) shared his version, the ability to provide timely and trustworthy information. Anderson (2000) also argued that communication is expected to be an interactive dialogue between the organization and its customers or potential customers. Disgruntled customers can be well serviced through a well formulated communization system. The medium of communication channel selected by the organization in dealing with the customers will prove the potency of the outcome of the communication in the long-run. It is therefore imperative on the part of the organization to select the most appropriate media vehicle which can easily be understood by the target market. Anything, short of this, will lead to conflict. Thus, Ball, Coelho and Machas (2004) mentioned that proper communication system can reduce relationship conflict.

H3: Relationship marketing has a positive relationship on customer communication.

\section{Conflict handling}

Conflict to a large extent is an inevitable phenomenon in today's busines proceedings. The proper handling of conflict between management and customers will boost the survival of the existing relationship. Scholars such as 
Dwyer, (2007); Ndubisi (2004); Narteh; (2013) and Chan, (2005) have contributed significantly on this field of conflict handing in business. In reference to Dwyer (2007) conflict handling basically is the ability to avoid potential conflict, solve manifest conflict before they create problems and discuss solutions openly when problems do arise. Song (2006) is of the opinion that conflict handling is a constructive or destructive effect on an organization thus, the organization should maximize its constructive benefits. Narteh. (2013) argued that management's ability to handle conflicts that arises between them and their customers will have a great impact on customer's satisfaction. Thus, conflict should be handled in a manner that will eliminate unnecessary losses (Ndubisi, 2004).

H4: Relationship marketing has a positive relationship on customer conflict handling.

\section{Bonding}

Wilson (2005) revealed that bonding is "the degree of mutual personal friendship and liking shared by the buyer and seller. He further classified bonding into two categories: social bond and structural bond. Social bond has a number of dimensions including; social interaction, closeness, and friendship and performance satisfaction. Heide and John (2002) viewed bonding as the dimension of business relationship that results in two parties (buyer and seller) acting in a unified manner towards a desired goal. Bonding has its root from relationship management, where it was used to indicate good personal relations. Dominici and Guzzo (2010) posited that business entities stand a higher chance of retaining its customers when they have a bonding scheme which looks at financial and social bonds that generate economic benefits, such as price, discount or other financial incentives to secure customer loyalty. The dimension of bonding as it applies to relationship marketing consists of developing and enhancing customer loyalty, which results directly in feelings or affection, a sense of belonging to the relationship, and indirectly in a sense of belonging to the organization.

H5: Relationship marketing has a positive relationship on customer bonding.

\section{Competence}

Competence can be viewed as the quality or extent of being competent. It can emanate from formal or conscious skills acquired through years of experience on the job. Management is expected to exhibit these skills relationally in order to retain the customer they come in contact with. The individual customers dealing with the business entity should be assured with competence both in process and procedure. Anderson and Weitz, (2002) viewed competence in relation to how consumers perceive the organization's usage of technology in discharging their contractual obligation they have with their customers. They categorized competence into four ways; (i) How the organization comprehend the consumer market. (ii) How they discharge their professional. (iii) How they help customers to plan their purchases. (iv) The ability to offer effective promotional materials. Thus, it is assumed that competence as a relationship marketing construct would have positive effect on customers (Narteh, 2013). Again, Song (2006) found a positive relationship between a bank's competence and its customer's satisfaction. Empirically, Das (2009) revealed that, organizational competence is one of the underlying reasons why a customer becomes glued to a company's services. Within the banking sector Chan (2005) explained competence to mean professional training and development of staff, deploying knowledgeable staff capable of identifying customer needs, having adequate knowledge of the various products and services, and providing quality and professional services to clients.

H6: Relationship marketing has a positive relationship on customer competence.

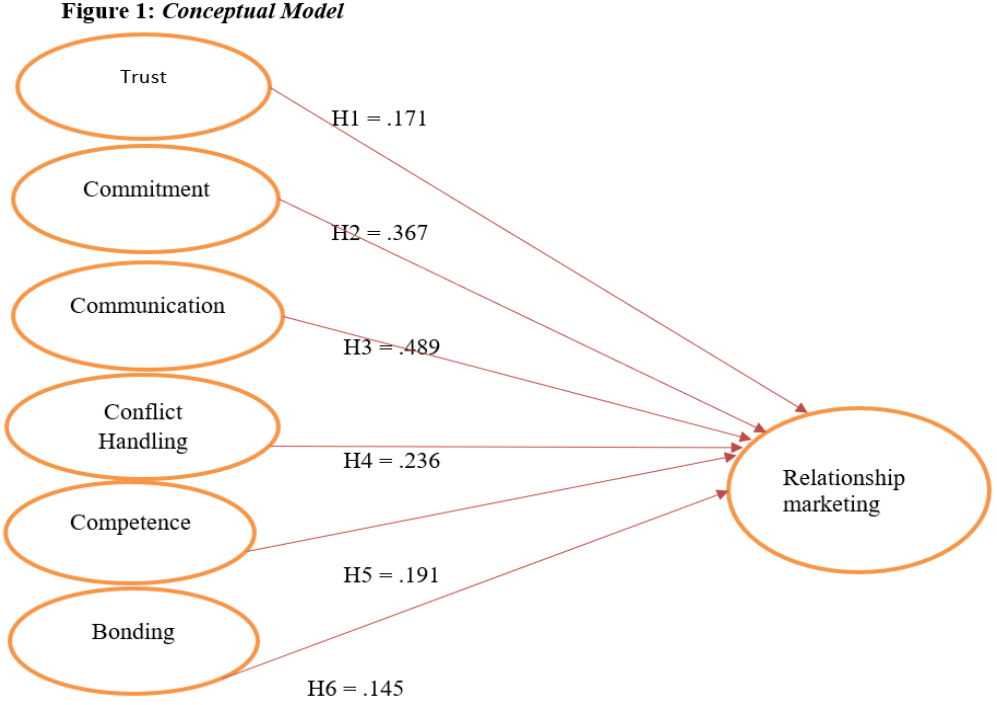


Methodology

A cross-sectional survey design was used for the study. Primary data were obtained with the aid of standardized instrument [questionnaires] while secondary data were obtained from extant literature. The target population of the study comprised of 16,217 customers of Five Ghanaian Banks namely Republic Bank, Zenith Bank, Cal Bank, Access Bank and National Investment Bank. This was obtained from the database of Bank of Ghana (2020). To ensure that adequate number of responses were received, the sample size was determined using Cresswell (2002) table of random sample size, therefore a sample size of 30 customers. Purposive sampling was used to select the five banks while the customers were selected using simple random sampling technique. Furthermore, the Cronbach's coefficient for the pilot study was 0.789 , which indicated a satisfactory level of significance.

\section{Results}

\section{Hypothesis 1- Trust has a positive relationship with relationship marketing}

From figure 1 it can be seen that there is a positive relationship between trust and relationship marketing $\left(R^{2}\right.$ $=.171, \mathrm{p}<0.05$ ), hence hypothesis one of the study was supported. Trust is proved to have a significant impact on competitive advantage based on the fact that customers with strong trust relationship with the bank turn to do more business with the bank. Thus, trust has a moderate positive relationship with relationship marketing. Thus, this result proves that a unit change in trust among stakeholders will induce a change in relationship marketing. In other words when trust of customers increases then competitive advantage also increases leading to customers doing more business with the bank. The significance level of this outcome according to the study results was 0.020 which is less than 0.05 indicating that the variance between the two variables in question was significant. These findings support the assertion by Guenzi and Pelloni (2004) and Ndubisi, (2004), Chan (2005) and Gibson (2007) in which relational marketing tactics and interpersonal relationship influence directly customer trust. They indicated that the prime (affluent) customers in majority, are influenced by relational marketing due to the fact that their chief objective in saving the money in the bank is for investment diversification purpose and trust is key to them.

\section{Hypothesis 2- If commitment has a positive relationship with relationship marketing.}

The results of the study as can be seen in figure 1, shows there is a positive relationship between commitment and competitive advantage is indicated; thus $\left(R^{2}=.367, \mathrm{p}<0.05\right)$, and hence hypothesis two of the study was accepted. In quintessence this result proves that a unit change in commitment level will induce a positive increase in competitive advantage. The significance level of this outcome in reference to the study results was 0.008 which is less than the standard value of 0.05 indicating that the variance between the two variables in question was significant.

\section{Hypothesis 3- Communication will have a significant influence on relationship marketing.}

From figure 1, the results show a strong positive correlation between communication and relationship marketing, thus $\left(R^{2}=.489, \mathrm{p}<0.05\right)$. It can be said thereof that communication is very essential in gaining competitive advantage leading to relationship marketing. In essence, this result proves that a unit change in communication will induce a positive change in relationship marketing. The significance level (p) of this outcome in reference to the study results was 0.00 which is less than the seamless value of significance 0.01 indicating that the variance between the two variables in question was extremely significant. Hence the hypothesis three of the study was accepted.

\section{Hypothesis 4- There is a positive relationship between conflict handling and relationship marketing.}

From figure 1, the results indicate that conflict handling has a moderate positive relationship on relationship marketing, thus $\left(R^{2}=.236, \mathrm{p}<0.01\right)$. It can be said thereof that when the banks have good structure of handling conflict, then customer loyalty increase leading to relationship marketing. In essence, this result depicts that a unit change in conflict handling will induce a positive increase in competitive advantage through relationship marketing by the banks. The significance level (p) of this outcome with respect to the study results was 0.026 which is less than the generally regarded value of significance 0.05 , indicating that the variance between the two variables under discussion was significant. Hence the hypothesis four of the study was accepted.

\section{Hypothesis 5- Competence will have a positive impact on relationship marketing}

From figure 1, the result shows there is a positive relationship between competence and relationship marketing $\left(R^{2}=.191, \mathrm{p}<0.05\right)$, hence hypothesis five of the study was supported. Competence is proved to have a significant impact on relationship marketing on banks understudy. Thus, competence has a moderate positive relationship with relationship marketing. In essence, holding all other variables constant, competence induces a high level of relationship marketing. The significance level of this outcome according to the study results was 0.031 which is less than 0.05 indicating that the variance between the two variables in question was significant.

\section{Hypothesis 6- Bonding is likely to have a positive relationship on relationship marketing}

From figure 1, presupposes that ability to bond has a high impact on relationship marketing, thus $\left(R^{2}=.145, \mathrm{p}<\right.$ 0.05). It can be said that banks have a high level of bonding that would lead to a high positive relationship on competitive advantage leading to relationship marketing. In essence, this result portrays that a unit change in banks' 
ability to bond will cause an increase change in the sustainability of competitive advantage through relationship marketing. The significance level (p) of this finding with respect to the study results was 0.006 which is less than the generally regarded value of significance 0.05 , indicating that the variance between the two variables under discussion was significant. Hence the sixth hypothesis of the study was accepted.

\section{Conclusion}

This paper examines the era of competitive advantage through relational marketing by banks. By using customer trust, customer commitment, customer communication, customer conflict handling, consumer competence and customer bonding as the intervening variables, this study confirms that relationship-centered marketing can influence this variable leading to customer loyalty. This study reaffirms the importance of relationship marketing. In the banking industry, competitive edge is very important and makes a plat when the customer is ready to stay maximum time with the organization and causes long-term benefit, but also provides a name of inspiration with the company services. It is important to banks to optimize the technology usage, both in the way that banks analyze customer data internally and the way they communicate information to their customers. When analyzing client activity, banks could use the technology to predict the trends rather than simple shifts in volumes. By applying smart systems, which automatically generate market news on customer financial performance and new ventures, banks could generate possible avenues for new banking solutions. Therefore, banks should create and use customer reporting as a result of a focus on relationship marketing. The most effective banks, like any organization that systematically sets out to convert customers into advocates, should put customer loyalty at the heart of their growth strategies. Banks need to provide a service that goes well beyond the ordinary to reap the truly attractive rewards that come to those that understand, relentlessly pursue and merit the loyalty of the most attractive customer segments.

\section{References}

Adamson, A., Chan, S. and Hanford, V. (2003), 'Behavioural Responses to Customer Satisfaction: An Empirical Study,' European Journal of Marketing, 35(5/6), 687-707.

Anderson, A. (2000), 'The Influence of Relationship Marketing Tactics on Customer's Loyalty in B2C Relationship- The Role of Communication and Personalization,' European Journal of Economics, Finance and Administrative Sciences, 5(31), 49-56.

Anderson, A. \& Weitz, C. (2002), 'Customer Loyalty in Retail Banking: Global Edition 14 (37),45-49 Boston: Bain \& Co. Inc.

Ambler, D. (2004), 'The Role of Communication and Trust in Explaining Customer Loyalty,' European Journal of Marketing, 38(9), 1272-1293.

Ball, J. Coelho, T and Machas, M. (2004), 'Predictors of Equity in Relationships Between Financial Services Providers and Retail Customers,' International Journal of Bank Marketing, 16(1), 15-23.

Bank of Ghana (2020). Annual reports. Retrieved [July, 2011] from http:/www.bog.gh.com.

Becker, L. (2001), 'The Relationship Between Customer Loyalty and Customer Satisfaction,' International Journal of Hospitality Management, 13(5), 213-217.

Bell, C. (2008), 'Service Quality, Trust, Specific Asset Investment and Expertise, Direct and Indirect Effects in a Satisfaction-Loyalty Framework,'Academy of Marketing Science, 34(16), 613-627.

Buttle, A. (2006), 'The Effects of Industry Knowledge on the Development of Trust in Service Relationships,' International Journal of Research in Marketing, 20(1), 31-43.

Chan, D. (2005), 'Investments in Consumer Relationships: A Cross-Country and Cross-Industry Exploration,' Journal of Marketing 65(4), 33-50.

Chen, T and Popovich, E. (2003), 'Marketing Management and Strategy,' 3rd ed. London: Prentice Hall International.

Churchill, H and Surpenam, W. (2002), 'Relationship Bonding Tactics, Relationship Quality and Customer Behavioral Loyalty - Behavioral Sequence in Taiwan's Information Services Industry,' Journal of Services Research, 6(1), 31-57.

Christopher, T. (2001), 'Managing Relationship Efforts to Influence Loyalty: An Empirical Study on the Sun Link Sea Forest and Recreational Park, Taiwan,' The International Journal of Organizational Innovation, 2(1), 179-194.

Creswell, J. W. (2008). Research design: Qualitative approach. Thousand Oaks, CA: Sage.

Das, S. (2009), 'Applying the Service Profit Chain in a Retail Environment: Challenging the 'Satisfaction Mirror', International Journal of Service Industry Management, 11(3), 244- 268.

Dwyer, R. (2007), 'Developing Buyer-Seller Relationship,' Journal of Marketing, 51(2), 11-27.

Fullerton, R. (2003), 'Impact of Participative Service Relationships on Quality, Sat isfaction and Retention: An Exploratory Study,' Journal of Business Research, 46(2), 121-132.

Garbarino, E. and Johnson, M. (2001), 'The Different Roles of Satisfaction, Trust and Commitment in Customer 
Relationships,' Journal of Marketing, 63(2), 70-87

Gibson, C. (2007), 'Relationship Approach to the Marketing Function in Service: The Marketing and Organizational Behaviour Interface,' Journal of Business Research, 20 (1), 3-12

Gummesson, E. (2009), 'Total Relationship Marketing - Rethinking Marketing Management: From 4PS to 30S,' Butterworth: Heinermann.

Heide, D and John, C. (2002), 'From Marketing Mix to Relationship Marketing: Towards a Paradigm Shift in Marketing,' Management Decision, 32(2), 4-20

Johnson, C. (2009), 'Relationship Marketing: Strategic and Tactical Implications,' Management Decision, 32, (2), 4-20.

Kotoroy, P. (2003), 'The Impact of Interpersonal Relationships on Customer Satisfaction and Loyalty to the Service Provider,' International Journal of Service Industry Management, 15(4), 365- 384.

Lambert, E. (2010), 'Ethical and Legal Foundations of Relational Marketing Exchanges,' Journal of Marketing, 57(4), 35-47.

Lindgren, J.V. (2004), 'The Effect of Relationship Banking on Customer Loyalty in the Retail Business Banking Industry,' Thesis, Graduate School of Business Leadership, University of South Africa.

McDonald, R. (1996), 'The Relationships of Customer Satisfaction, Customer Loyalty, and Profitability: An Empirical Study,' International Journal of Service Industry Management, 7(4), 27-42.

Moorman, M. (2003), 'Online Customer Stickiness: A Longitudinal Study,' Journal of Global Information Management, 10(3), 57-68

Morgan, RM. and Hunt, SD. (2004), 'The Commitment-Trust Theory of Relationship Marketing,' Journal of Marketing, 58(3), 20-38.

Murphy, A. (2003), 'Competitive Conditions in Banking Industry: An Empirical Analysis of the Consolidation, Competition and Concentration in the Indonesia Banking Industry between 2001 and 2009,' Bulletin of Monetary Economics and Banking, 14(2), 141-176.

Narteh, H. (2013), 'Effects of Trust and Governance on Relational Risk,' Academy of Management Journal, 40(2), 308-339.

Ndubisi, N. O. (2004), 'Supplier-Customer Relationship Management and Customer Loyalty: The Banking Industry Perspective,' Journal of Enterprise Information Management, 20(2):222-236.

Phan, J.A. (2003), Internal Marketing and the Antecedents of Nurse Satisfaction and Loyalty,' Health Marketing Quarterly, 23(4), 75-108.

Pointer, C. (2006), 'Relationship Marketing in Consumer Markets. Rhetoric or Reality?' European Journal of Marketing, 34(7), 797-815.

Proctor, T. (2000), 'Strategic Marketing: An Introduction,' London: Routledge.

Sin, J.N. and Tse, A. (2005), 'The Evolution of Relationship Marketing,' In Sheth, JN. and Parvatiyar, A. (eds), Handbook of Relationship Marketing. Thousand Oaks/London/New Delhi: Sage

Song, D. (2006), 'Agency and Trust Mechanisms in Consumer Satisfaction and Loyalty Judgments,' Journal of the Academy of Marketing Science, 28(1), 150-167.

Urban, S. S., Sultan, S.W. and Qualls, M. (2000), 'Customer Evaluations of Service Complaint Experiences: Implications for Relationship Marketing,' Journal of Marketing, 62(2), 60- 77.

Wilson, W. (2005), 'Placing Trust at the Center of Your Internet Strategy,' Sloan Management Review, 42(1), 3948. 